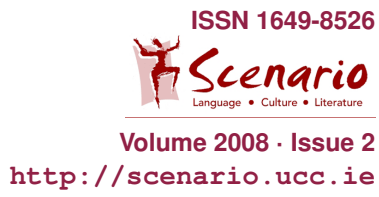

TaT - Texts around Theatre - TaT

\title{
Teacher Man
}

A Memoir

Frank McCourt

\begin{abstract}
Frank McCourt (*1930), US-American author of Irish descent and Pulitzer Prize laureate (1997) became internationally known through his childhood memoirs Angela's Ashes (1996). His autobiographical text Teacher Man (2005) revolves around memories that are closely tied to his pedagogical profession. The following excerpt traces back his 30 -year teaching career to experiences during his adolescence. The purchase of his first book, a one-volume edition of the works of Shakespeare, and his first encounters with Shakespeare via radio and travelling theatre become formative and confusing experiences.
\end{abstract}

\section{Teacher Man: A Memoir}

I went to O'Mahony's Bookshop to buy the first book in my life, the one I brought to America in the suitcase.

It was The Works of William Shakespeare: Gathered into One Volume, published by the Shakespeare Head Press, Oldhams Press Ltd. and Basil Blackwood, MCMXLVII. Here it is, cover crumbling, separating from the book, hanging on through the kindness of tape. A well-thumbed book, well marked. There are passages underlined that once meant something to me though I look at them now and hardly know why. Along the margins notes, remarks, appreciative comments, congratulations to Shakespeare on his genius, exclamation marks indicating my appreciation and befuddlement. Inside the cover I wrote, 'Oh, that this too, too solid flesh, etc.' It proves I was a gloomy youth.

When I was thirteen/fourteen I listened to Shakespeare plays on the radio of Mrs. Purcell, the blind woman next door. She told me Sheakespeare was an Irishman ashamed of what he came from. A fuse blew the night we listened to Julius Caesar and I was so eager to find out what happened to Brutus and Mark Antony I went to O'Mahony's Bookshop to get the rest of the story. A sales clerk in the shop asked me in a superior way if it was my intention to buy that book and I told him I was thinking about it but first I'd have to find out what happened to everyone in the end, especially the one I liked, Brutus. The 
man said never mind Brutus, pulled the book away from me and said this was not a library and would I kindly leave. I backed into the street embarrassed and blushing and wondering at the same time why people won't stop bothering people. Even when I was small, eight or nine, I wondered why people won't stop bothering people and I've been wondering ever since.

The book was nineteen shillings, half a week's wages. I wish I could say I bought it because of my profound interest in Shakespeare. It wasn't that way at all. I had to have it because of a film I saw where an American soldier in England went around spouting Shakespeare and all the girls fell madly in love with him. Also, if you even hint that you read Shakespeare, people give you that look of respect. I thought if I learned long passages I'd impress the girls of New York. I already knew 'Friends, Romans, countrymen', but when I said it to a girl in Limerick she gave me a curious look as if I were coming down with something.

Going up O'Connell Street I wanted to unwrap my package and let the world see me with Shakespeare in my oxter but I didn't have the nerve. I passed the small theater where I once saw a travelling company perform Hamlet and remembered how I felt sorry for myself for the way I'd suffered like him. At the end of the play that night Hamlet himself returned to the stage to tell the audience how grateful he and the cast were for our attendance and how weary he was, he and the cast, and how much they'd appreciate our help in the form of small change, which we could deposit in the lard tin by the door. I was so moved by the play because so much of it was about me and my gloomy life that I dropped sixpence into the lard tin and wished I could have attached a note to let Hamlet know who I was and how my suffering was real and not just in a play.

Next day I delivered a telegram to Hanratty's Hotel and there was the cast from Hamlet, drinking and singing in the bar while a porter ran back and forth loading a van with their luggage. Hamlet himself sat alone at the end of the bar, sipping his glass of whiskey, and I don't know where the courage came from but I said hello to him. After all, we both had been betrayed by our mothers and our suffering was great. The world would never know about mine and I envied him for the way he was able to express his anguish every night. Hello, I said, and he stared at me with two black eyes under black eyebrows in a white face. He had all those words from Shakespeare in his head but now he kept them there and I blushed like a fool and tripped over my feet.

I rode my bicycle up O'Connell Street in a state of shame. Then I remembered the sixpence dropped into the lard tin, sixpence that paid for their whiskey and singing at Hanratty's Bar, and I wanted to go back and confront the whole cast and Hamlet himself and tell them what I thought of them with their false stories of weariness and the way they drank the money of poor people.

Let the sixpence go. If I went back they'd surely throw Shakespeare words at me and Hamlet would stare at me again with his cold black eyes. I'd have no words for that and I'd look foolish if I tried staring back at him with my red eyes.

From:

Frank McCourt (2005) Teacher Man: A Memoir. London, Fourth Edition, p. 35-37 